\title{
Association between polymorphisms in the flanking region of the TAFI gene and atherosclerotic cerebral infarction in a Chinese population
}

\author{
You Li ${ }^{1 \dagger}$, Zhiliang Zeng ${ }^{2 \dagger}$, Jianghao Zhao ${ }^{2 \dagger}$, Guoda Ma', Lili Cui ${ }^{1}$, Hua Tao ${ }^{2}$, Zhijun Lin², Yanyan Chen ${ }^{1}$, Bin Zhao ${ }^{1,2}$, \\ Yusen Chen ${ }^{2^{*}}$ and Keshen $\mathrm{Li}^{i^{*}}$
}

\begin{abstract}
Background: Atherosclerosis is the leading etiologic factor of Atherosclerotic Cerebral Infarction (ACI). Previous studies have shown that thrombin activatable fibrinolysis inhibitor (TAFI) may play an important role in the occurrence of acute cerebral infarction, and the levels of TAFI are affected by several single nucleotide polymorphisms (SNPs) located in the regulatory and coding regions of the gene encoding TAFI. The present study aimed to determine whether polymorphisms (TAFI -2345 2G/1G, $-1690 \mathrm{~A} / \mathrm{G},-438 \mathrm{~A} / \mathrm{G},+1583 \mathrm{~A} / \mathrm{T}$ ) of the TAFI gene were associated with $\mathrm{ACl}$ in a Han Chinese population.

Methods: The variant genotypes were identified by restriction fragment length polymorphism (RFLP) and allele-specific polymerase chain reactions (AS-PCR) in 225 patients with $\mathrm{ACl}$ and 184 age-matched healthy individuals.

Results: There was a significant difference in the genotype and allele frequencies of TAFI -2345 2G/1G and -1690 $\mathrm{A} / \mathrm{G}$ polymorphisms between the $\mathrm{ACl}$ and control subjects. Further stratification analysis by gender revealed that the presence of the $-438 \mathrm{AA}$ genotype and the A allele conferred a higher risk of developing $\mathrm{ACl}$ in male patients $(\mathrm{p}<0.05)$. Haplotype analysis demonstrated that four haplotypes of TAFI are significantly associated with ACI.
\end{abstract}

Conclusions: Our study provides preliminary evidence that the TAFI -2345 2G/1G and -1690 A/G polymorphisms are associated with $\mathrm{ACl}$ susceptibility in a Han Chinese population.

Keywords: Thrombin activatable fibrinolysis inhibitor (TAFI), Atherosclerotic Cerebral Infarction (ACI), Polymorphism

\section{Background}

Thrombin activatable fibrinolysis inhibitor (TAFI), also known as carboxypeptidase B2 (CPB2), is a basic carboxypeptidase $[1,2]$. TAFI can be activated by trypsin-like enzymes, such as thrombin, plasmin, and the thrombin/ thrombomodulin complex. Activated TAFI removes $\mathrm{C}$-terminal lysine residues on plasmin-modified, partially degraded fibrin and attenuates the rate of plasminogen activation, thus playing a significant role in

\footnotetext{
* Correspondence: yusenchen163@163.com; likeshen1971@126.com 'Equal contributors

2Department of Neurology, Affiliated Hospital of Guangdong Medical College, Zhanjiang 524001, China

${ }^{1}$ Guangdong Key Laboratory of Age-Related Cardiac and Cerebral Diseases, Affiliated Hospital of Guangdong Medical College, Zhanjiang 524001, China
}

blood coagulation and fibrinolysis. An imbalance between the processes of coagulation and fibrinolysis is one of the main contributors to thrombosis, a key factor for the onset of atherosclerotic cerebral infarction (ACI) [1,3-5]. Impaired fibrinolysis may also be a risk factor for arterial thrombotic events [6]. In addition, an increased plasma TAFI concentration may be a risk factor for multiple diseases, including stable angina pectoris [7], coronary artery disease [8,9], myocardial infarction (MI) [10], and venous thrombosis [11-13]. Therefore, the risk of cardiovascular disease, in general, may be decreased by lowering plasma TAFI levels.

The TAFI gene maps to chromosome 13q14.11, spans approximately $48 \mathrm{~kb}$ and contains 11 exons. Several SNPs located in the flanking region of TAFI have been 
shown to modify plasma TAFI antigen levels [14-16]. Franco et al. demonstrated that polymorphisms in the TAFI promoter determine plasma antigen levels and may influence the risk of venous thrombophilia [14]. Henry et al. revealed that circulating levels of TAFI are strongly determined by polymorphic variations in the promoter and the 3'-untranslated region (UTR) of the TAFI gene [15]. In addition, Biswas et al. determined that TAFI antigen levels were significantly associated with the disease phenotype and with TAFI polymorphisms [17]. These findings suggest that TAFI polymorphisms may play a role in modulating plasma TAFI antigen level, and thus contribute to ACI phenotype.

Association studies between polymorphisms of TAFI and stroke have been reported for many different origin populations, but with conflicting results [17-19]. Akatsu et al. found no statistical correlation between TAFI Ala147Thr and Thr325Ile polymorphisms and cerebral infarction [18]. Ladenvall et al. also did not find any association between genetic variants of TAFI and overall ischemic stroke, but they did find an increased risk between TAFI polymorphisms and stroke subtypes [20]. More recently, Kozian et al. found that the Ile/Ile genotype at position 325 of TAFI is associated with the incidence of stroke and the age at onset of first stroke [19]. Furthermore, the incidence of stroke is higher in TAFI Ile325Ile patients with predisposing risk factors for thrombotic events, such as diabetes mellitus, myocardial infarction or hypertension [19]. These lines of evidence suggest a role for TAFI polymorphisms in the pathogenesis of stroke. However, the association between TAFI polymorphisms and ACI has not yet been determined. Therefore, the present study aims to evaluate the existence of an association between four polymorphisms $(-23452 \mathrm{G} / 1 \mathrm{G},-1690 \mathrm{~A} / \mathrm{G},-438 \mathrm{~A} / \mathrm{G}$ and $+1583 \mathrm{~A} / \mathrm{T})$ of TAFI and ACI in a case-controlled study of a Han Chinese population.

\section{Methods}

\section{Study population}

The study recruited 225 patients with ACI (145 males and 80 females) from the Department of Neurology at the Affiliated Hospital of Guangdong Medical College in China between 2011 and 2013. Patients' diagnoses were verified with either computed tomography (CT) or magnetic resonance imaging (MRI) and were cliniconeuropathologically confirmed. Patients were classified into subtypes according to the Trial of Org 10172 in Acute Stroke Treatment (TOAST) classification [21]. Patients with transient ischemic attacks, cardiogenic cerebral infarctions, cerebral hemorrhage, coronary artery diseases, autoimmune diseases, systemic inflammatory diseases, blood diseases, or malignant tumors were excluded from this study. Additional information recorded included age, gender, cerebrovascular disease risk factors and previous and ongoing medication or systemic therapy.

A total of 184 matched controls (107 males and 77 females) were recruited from the Health Examination Center of the Affiliated Hospital of Guangdong Medical College during the same time period. These control patients were comparable to the ACI subjects in age, sex, and race. The same exclusion criteria were used as above. Written informed consent was obtained from each participant prior to enrollment in the study. The study was approved by the ethics committee of Guangdong Medical College and was conducted according to the principles of the Declaration of Helsinki.

\section{Genotyping of TAFI polymorphisms}

Genomic DNA was extracted from peripheral blood using the EZ-10 Spin Column Whole Blood Genomic DNA Isolation Kit (Sangon Biotech ${ }^{\circ}$, Shanghai, China) according to the manufacturer's instructions. Four TAFI SNPs $(-2345$ 2G/1G, -1690 A/G, -438 A/G and +1583 $\mathrm{A} / \mathrm{T})$ were selected according to previous findings [15]. Genotyping of the TAFI gene for the presence of -438 $\mathrm{A} / \mathrm{G}$ and $+1583 \mathrm{~A} / \mathrm{T}$ mutations was performed by polymerase chain reaction (PCR) and restriction fragment length polymorphism (RFLP); TAFI -2345 2G/1G and $1690 \mathrm{~A} / \mathrm{G}$ mutations were identified by allele-specific polymerase chain reaction (AS-PCR). The primers used are listed in Table 1. The PCR and RFLP analysis were

Table 1 Methods and primers used in genotyping of TAFI -438 A/G, +1583 A/T, -1690 A/G and -2345 2G/1G polymorphisms

\begin{tabular}{|c|c|c|}
\hline Gene polymorphisms & Analysis & Primers \\
\hline \multirow[t]{2}{*}{ TAFI -438 A/G } & PCR-RFLP & Forward:ACCAATGGGAATGTAGG \\
\hline & & Reverse:CCTTGCCTCTGACTITT \\
\hline \multirow[t]{2}{*}{ TAFI +1583 A/T } & PCR-RFLP & Forward:CTTGGCATGTCATTAGG \\
\hline & & Reverse:TGCGGCATTTGTTGACA \\
\hline \multirow[t]{4}{*}{ TAFI -1690 A/G } & AS-PCR & $\begin{array}{l}\text { Common Forward a:CACCTGTA } \\
\text { GACTITGC }\end{array}$ \\
\hline & & $\begin{array}{l}\text { Special Forward a1:TTAACTATTT } \\
\text { TGACTGTTA }\end{array}$ \\
\hline & & $\begin{array}{l}\text { Special Forward a2:TTAACTATTT } \\
\text { TGACTGTTTG }\end{array}$ \\
\hline & & $\begin{array}{l}\text { Common Reverse b: CACTGAAG } \\
\text { GAGAGAAAG }\end{array}$ \\
\hline \multirow[t]{4}{*}{ TAFI -2345 2G/1G } & AS-PCR & $\begin{array}{l}\text { Common Forward a:CACCTCAA } \\
\text { CTGGACTATGT }\end{array}$ \\
\hline & & $\begin{array}{l}\text { Special Forward a1:AGTTTTAAA } \\
\text { ACATGAAAGA }\end{array}$ \\
\hline & & $\begin{array}{l}\text { Special Forward a2:AGTTITAAA } \\
\text { ACATGAAAGGA }\end{array}$ \\
\hline & & $\begin{array}{l}\text { Common Reverse b: TGTTCCCTT } \\
\text { GCAGTTAGC }\end{array}$ \\
\hline
\end{tabular}


performed as described previously [22]. For quality control, we sequenced 5\% DNA samples directly for each SNP, and no inconsistencies were detected. The results were read and interpreted in a blind fashion, without knowledge of the patient's designated group.

\section{Statistical analysis}

All statistical tests were performed using SPSS 19.0 software (IBM, Armonk, NY, USA). The Hardy-Weinberg equilibrium and differences in the gene and allele frequencies between groups were assessed using a $\chi^{2}$ test. The allele and genotype frequency differences between patient cases and healthy controls were assessed by Fisher's exact test or the chi-square test. For comparisons resulting in significant statistical values, an odds ratio (OR) with a 95\% confidence interval (95\% CI) was calculated by comparing the total number of each allele found among the cases and controls. Haplotype analyses were conducted by SHEsis software (http://analysis.bio-x.cn/myAnalysis.php) [23]. All p values reported were two-tailed. Statistical significance was defined as $\mathrm{p}<0.05$.

\section{Results}

\section{Baseline characteristics}

The clinical characteristics of the 409 participants (225 ACI patients and 184 control subjects) are presented in Table 2. Conventional risk factors, including smoking, hypertension, and diabetes, were significantly more common in the ACI group than in the control group. There were no significant differences in age or sex between the $\mathrm{ACI}$ patients and controls. The mean ages of the ACI and control patients were 67.60 years old $( \pm 10.61$ years) and 66.11 years old ( \pm 11.02 years), respectively. In ACI patients, the blood glucose levels tended to be higher than in the controls, but the high-density lipoprotein

Table 2 General characteristics of patients with $\mathrm{ACl}$ and controls

\begin{tabular}{lll}
\hline Variables & Cases $(\mathbf{n}=\mathbf{2 2 5})$ & Controls $(\mathbf{n}=\mathbf{1 8 4})$ \\
\hline Age (years) (mean $\pm \mathrm{SD})$ & $67.60 \pm 10.61$ & $66.11 \pm 11.02$ \\
Sex (male/female) & $145 / 80$ & $107 / 77$ \\
Smoking $(\%, \mathrm{n})$ & $21.8 \%(49) *$ & $13.0 \%(24)$ \\
Hypertension & $64.4 \%(145)^{*}$ & $23.9 \%(44)$ \\
Diabetes & $23.1 \%(52)^{*}$ & $6.0 \%(11)$ \\
Blood glucose levels (mmol/L) & $6.51 \pm 2.60^{*}$ & $5.43 \pm 1.70$ \\
Cholesterol (mmol/L) & $5.17 \pm 1.35$ & $5.30 \pm 1.18$ \\
Triglyeride (mmol/L) & $1.23 \pm 0.72$ & $1.27 \pm 0.86$ \\
High density lipoprotein (HDL) & $1.28 \pm 0.28^{*}$ & $1.45 \pm 0.41$ \\
(mmol/L) & & \\
Low density lipoprotein (LDL) & $3.36 \pm 1.02$ & $3.31 \pm 0.94$ \\
(mmol/L) & & \\
*P $<0.05$. & &
\end{tabular}

(HDL) levels were lower at admission. The cholesterol, triglyceride and low-density lipoprotein (LDL) levels of the ACI patients were not significantly different from those of the healthy control patients.

\section{Genotype and allele frequencies of TAFI polymorphisms in $\mathrm{ACl}$ patients and controls}

The genotype and allele frequencies of the TAFI gene polymorphisms are shown in Table 3. No deviation from the Hardy-Weinberg equilibrium for the polymorphisms examined was observed in the genotype distributions of the ACI patients and controls (data not shown).

The comparison of genotype distributions between the ACI subjects and control subjects revealed that there was a statistically significant association between the 2345 2G/1G and -1690 A/G polymorphisms of TAFI and the risk of $\mathrm{ACI}$. The $2 \mathrm{G}$ versus $1 \mathrm{G}$ allele frequencies of the TAFI -2345 2G/1G polymorphism were $57.1 \%$ versus $42.9 \%$ among the patient cohort and $49.2 \%$ versus

Table 3 Allele and genotype frequencies of the TAFI polymorphisms in $\mathrm{ACl}$ patients and controls

\begin{tabular}{|c|c|c|}
\hline \multirow[t]{2}{*}{ TAFI Polymorphisms } & \multicolumn{2}{|c|}{ Frequency } \\
\hline & Cases $(n=225)$ & Controls $(n=184)$ \\
\hline \multicolumn{3}{|l|}{$-23452 \mathrm{G} / 1 \mathrm{G}$} \\
\hline $2 \mathrm{G} / 2 \mathrm{G}$ & $66(29.3 \%)$ & $42(22.8 \%)$ \\
\hline $2 \mathrm{G} / 1 \mathrm{G}$ & $125(55.6 \%)$ & $97(52.7 \%)$ \\
\hline $1 \mathrm{G} / 1 \mathrm{G}$ & $34(15.1 \%)^{*}$ & $45(24.5 \%)$ \\
\hline $2 \mathrm{G}$ & $257(57.1 \%)$ & $181(49.2 \%)$ \\
\hline $1 \mathrm{G}$ & $193(42.9 \%)^{*}$ & $187(50.8 \%)$ \\
\hline \multicolumn{3}{|l|}{$-1690 \mathrm{~A} / \mathrm{G}$} \\
\hline AA & $110(48.9 \%)^{*}$ & 72(39.1\%) \\
\hline$A G$ & $96(42.7 \%)$ & $86(46.7 \%)$ \\
\hline GG & 19(8.4\%) & $26(14.2 \%)$ \\
\hline A & $316(70.2 \%)^{*}$ & $230(62.5 \%)$ \\
\hline G & 134(29.8\%) & 138(37.5\%) \\
\hline \multicolumn{3}{|l|}{$-438 \mathrm{~A} / \mathrm{G}$} \\
\hline GG & $122(54.2 \%)$ & $108(58.7 \%)$ \\
\hline GA & 87(38.7\%) & $67(36.4 \%)$ \\
\hline $\mathrm{AA}$ & 16(7.1\%) & $9(4.9 \%)$ \\
\hline G & $331(73.6 \%)$ & $283(77.0 \%)$ \\
\hline A & $119(26.4 \%)$ & $85(23.0 \%)$ \\
\hline \multicolumn{3}{|l|}{$+1583 \mathrm{~A} / \mathrm{T}$} \\
\hline$\pi$ & $129(57.3 \%)$ & 99(53.8\%) \\
\hline TA & $81(36.0 \%)$ & $78(42.4 \%)$ \\
\hline $\mathrm{AA}$ & $15(6.7 \%)$ & $7(3.8 \%)$ \\
\hline $\mathrm{T}$ & $339(75.3 \%)$ & $276(75.0 \%)$ \\
\hline A & $111(24.7 \%)$ & $92(25.0 \%)$ \\
\hline
\end{tabular}

${ }^{*} \mathrm{P}<0.05$. 
$50.8 \%$ among control subjects $(\mathrm{p}<0.05)$. The prevalence of the TAFI $-23452 \mathrm{G} / 2 \mathrm{G}(\mathrm{p}=0.017, \mathrm{OR}=0.550,95 \%$ CI: 0.335-0.903) genotype and the $-23452 \mathrm{G}(\mathrm{p}=0.024$, $\mathrm{OR}=0.727,95 \%$ CI: 0.551-0.959) allele frequencies was significantly higher in patients than in controls. Likewise, the A versus $\mathrm{G}$ allele frequencies of the TAFI $-1690 \mathrm{~A} / \mathrm{G}$ polymorphism were $70.2 \%$ versus $29.8 \%$ among the patient cohort and $62.5 \%$ versus $37.5 \%$ among control subjects $(\mathrm{p}<0.05)$. The prevalence of the -1690 AA genotype $(\mathrm{p}=0.048 ; \mathrm{OR}=1.488,95 \% \mathrm{CI}: 1.002-2.209)$ and the 1690 A allele $(\mathrm{p}=0.048 ; \mathrm{OR}=1.488,95 \%$ CI: $1.002-2.209)$ frequencies was significantly higher in patients than in controls. No differences in the $-438 \mathrm{~A} / \mathrm{G}$ and $+1583 \mathrm{~A} / \mathrm{T}$ genotype and allele frequencies were observed between ACI cases and control subjects (Table 3).

Stratification of the genotype and allele frequencies of TAFI polymorphisms in $\mathrm{ACl}$ patients and controls by gender

When stratified by gender, a significant difference was found in the frequency of the A allele of the TAFI -438 $\mathrm{A} / \mathrm{G}$ polymorphism between male ACI patients and male controls $(\mathrm{p}=0.039$; OR $=1.549$ (95\% CI: $1.020-2.353)$. In female individuals, no significant difference of genotype or allelic distribution was found between the ACI and control groups. We did not observe differences of TAFI $+1583 \mathrm{~A} / \mathrm{T},-2345$ 2G/1G and $-1690 \mathrm{~A} / \mathrm{G}$ genotype and allele frequencies between ACI patients and controls when separated by gender (Table 4).

\section{Haplotype analysis}

We found a total of 16 haplotypes. Four haplotypes in which the frequency of the haplotype was greater than $5 \%$ in ACI cases and controls were included in the haplotype analysis. The haplotypes included yielded strongly significant associations (Table 5). The frequency of haplotypes H2 (2G/A/G/A) and H3 (2G/A/G/T) was significantly higher in the $\mathrm{ACI}$ case group than in the control group ( $\mathrm{p}=0.026 ; \mathrm{p}=0.002$, respectively); whereas the haplotype frequencies for $\mathrm{H} 1(\mathrm{G} / \mathrm{G} / \mathrm{G} / \mathrm{T})$ and $\mathrm{H} 4$ $(2 \mathrm{G} / \mathrm{G} / \mathrm{G} / \mathrm{T})$ were lower in the ACI cases $(\mathrm{p}=0.015$ and $\mathrm{p}=0.001$, respectively).

\section{Discussion}

The results of the present study provide evidence that the variant $-23452 \mathrm{G} / 1 \mathrm{G}$ and $-1690 \mathrm{~A} / \mathrm{G}$ polymorphisms of TAFI are associated with the risk of developing ACI in contrast with the $-438 \mathrm{~A} / \mathrm{G}$ and $+1583 \mathrm{~A} / \mathrm{T}$ polymorphisms. To the best of our knowledge, this result is the first to suggest an association of the -2345 2G/1G and -1690 A/G polymorphisms of TAFI with ACI in a Chinese population. Further stratification by gender revealed that the $438 \mathrm{~A} / \mathrm{G}$ polymorphism of TAFI is associated with ACI in male patients. In addition, haplotype analysis demonstrated that four haplotypes are significantly associated with ACI.

TAFI is a $58-\mathrm{kDa}$ plasma glycoprotein secreted by hepatocytes as an inactive form [24]. Upon activation by thrombin, plasmin, or the thrombin-thrombomodulin complex, TAFI is transformed into a carboxypeptidase B-like enzyme (TAFIa) [2,25]. TAFla plays an important role in regulating the balance between coagulation and fibrinolysis by inhibiting fibrinolysis. Previous studies have indicated that high levels of TAFI in circulating plasma increase the risk of cardiovascular death during the acute phase of ischemic stroke [24]. In addition, recent studies have reported that TAFI deficient mice are also susceptible to intracerebral thrombosis and ischemic stroke [26]. These lines of evidence lead to the hypothesis that TAFI is of pathogenic significance to ACI.

Several studies have analyzed the relationship between TAFI polymorphisms and cardiovascular disease, with different and even contradictory conclusions drawn from various ethnical populations. While one study found that the 147Thr allele of the Ala147Thr polymorphism protected against MI [27], in another study, the $147 \mathrm{Thr}$ allele was associated with a higher risk of angina [28]. TAFI polymorphisms C+1542G and Thr325Ile were also found to be related to the type of ACS [29] and thrombotic microangiopathies [30]. Regarding cerebrovascular diseases, Akatsu et al. did not find any association between the Ala147Thr and Thr325Ile polymorphisms of TAFI and cerebral infarction [18]. However, a prospective cohort study in Europe demonstrated that the Thr325Ile polymorphism of TAFI is associated with the incidence of stroke and the age at onset of first stroke in patients [19]. Ladenvall et al. did not find any association between a series of tagging SNPs of the TAFI gene, but an increased risk was found between TAFI polymorphisms and stroke subtypes [20]. In the present study, we show, for the first time, that the $-23452 \mathrm{G} / 1 \mathrm{G}$ and -1690 $\mathrm{A} / \mathrm{G}$ polymorphisms of TAFI were associated with $\mathrm{ACI}$ in

Table 4 Subgroup analysis of TAFI -438A/G polymorphism genotype and allele frequencies of the men and women

\begin{tabular}{llllllll}
\hline Gender & Group & Number & GG & GA & AA & G & A \\
\hline Male & Cases & 145 & $75(51.7 \%)$ & $57(39.3 \%)$ & $13(9.0 \%)^{*}$ & $207(71.4 \%)$ & $83(28.6 \%)^{*}$ \\
\cline { 2 - 8 } & Controls & 107 & $65(60.7 \%)$ & $40(37.4 \%)$ & $2(1.9 \%)$ & $170(79.4 \%)$ & $44(20.6 \%)$ \\
\hline Female & Cases & 80 & $47(58.8 \%)$ & $30(37.4 \%)$ & $3(3.8 \%)$ & $124(77.5 \%)$ & $36(22.5 \%)$ \\
\cline { 2 - 8 } & Controls & 77 & $43(55.8 \%)$ & $27(35.1 \%)$ & $7(9.1 \%)$ & $113(73.4 \%)$ & $41(26.6 \%)$ \\
\hline
\end{tabular}

*Compare with control group, $P<0.05$. 
Table 5 Association analysis of TAFI haplotypes

\begin{tabular}{|c|c|c|c|c|c|c|c|c|c|}
\hline \multirow[t]{2}{*}{ NO } & \multicolumn{4}{|c|}{ Haplotypes } & \multirow[t]{2}{*}{ Cases } & \multirow[t]{2}{*}{ Controls } & \multirow[t]{2}{*}{$P$} & \multirow[t]{2}{*}{ OR } & \multirow[t]{2}{*}{$95 \% \mathrm{Cl}$} \\
\hline & -2345 & -1690 & -438 & +1583 & & & & & \\
\hline $\mathrm{H} 1$ & $1 G$ & G & $G$ & $T$ & $22.71(5.0 \%)$ & $34.50(9.4 \%)$ & 0.015 & 0.512 & $0.296 \sim 0.887$ \\
\hline $\mathrm{H} 2$ & $2 \mathrm{G}$ & $A$ & G & $A$ & $25.50(5.7 \%)$ & $9.26(2.5 \%)$ & 0.026 & 2.328 & $1.083 \sim 5.005$ \\
\hline $\mathrm{H} 3$ & $2 \mathrm{G}$ & A & G & $\mathrm{T}$ & 131.72(29.3\%) & 72.87(19.8\%) & 0.002 & 1.684 & $1.212 \sim 2.340$ \\
\hline $\mathrm{H} 4$ & $2 \mathrm{G}$ & G & G & $\mathrm{T}$ & 19.64(4.4\%) & $37.62(10.2 \%)$ & 0.001 & 0.399 & $0.227 \sim 0.703$ \\
\hline
\end{tabular}

Only haplotypes whose frequency was $>5 \%$ in both cases and controls were included in the Table.

a Chinese population. As demonstrated by Henry et al., the four polymorphisms investigated in the present study were in strong linkage disequilibrium with each other and with the previously described Ala147Thr polymorphism [15]. It is most likely that these polymorphisms function synergistically to contribute to the disease phenotype.

It has been widely recognized that plasma TAFI levels are strongly genetically controlled [17,31]. TAFI levels are under the control of several SNPs located in the regulatory and coding regions of the TAFI gene [17,18,25,32]. A transethnic study using fine mapping of quantitative trait nucleotides (QTNs) underlying TAFI antigen levels identified that the $-23452 \mathrm{G} / 1 \mathrm{G}$ SNP located in the 5 region might be one of the QTNs [33] and that $-23451 \mathrm{G}$ alleles were independently associated with increased TAFI levels. The $-1690 \mathrm{~A} / \mathrm{G}$ polymorphism is located two bases downstream from a potential binding site for the HFH3 transcription factor, and the $-438 \mathrm{~A} / \mathrm{G}$ polymorphism is located one base downstream from a potential binding site for the VBP transcription factor [14]. These polymorphisms may alter the binding of the corresponding transcription factors to the promoter, thus affecting promoter activity and contributing to varied TAFI expression. In the 3'-UTR, there are three transcription termination sites [34]. The interaction of cis-acting elements within the 3'-UTR of TAFI with IL-1 and IL-6 significantly increased the stability and frequency of mRNA transcripts [35]. In addition, polymorphisms in the 3'-UTR may alter TAFI mRNA abundance by influencing mRNA processing or stability. The haplotype carrying the $+1583 \mathrm{~T}$ allele reduces the stability of TAFI transcripts, suggesting the $+1583 \mathrm{~A} / \mathrm{T}$ allele is also related to TAFI antigen levels [14,15]. Data from Africans and Europeans converged to identify the $1583 \mathrm{~T} / \mathrm{A}$ polymorphism as one of the QTNs contributing to elevated TAFI levels. In sum, polymorphisms both in the promoter and 3'-UTR regions of TAFI can affect the binding of transcription factors or mRNA stability, thereby influencing gene expression.

The stratified analysis by gender revealed that among males, those with the variant $-438 \mathrm{~A}$ allele and AA genotype had a significantly higher risk of ACI, while among women, no statistical significance was found.
TAFI levels in patients with polycystic ovary syndrome (PCOS) were significantly higher than in control groups [36,37]. It is known that PCOS patients express high levels of androgen [36,37]. The androgen may affect TAFI production by some unknown mechanism. Therefore, it is conceivable that the -438 AA allele that is associated with higher androgen levels could also increase TAFI levels in male ACI patients. However, more functional studies on the relationship between sex hormones and TAFI levels should be carried out.

In genes with multiple susceptibility alleles, particularly when the LD between polymorphisms is weak, haplotype-based association studies have advantages over analyses based on individual polymorphisms [38]. In the present study, haplotype analysis identified four haplotypes significantly associated with ACI. H1(1G/G/G/T) and $\mathrm{H} 4(2 \mathrm{G} / \mathrm{G} / \mathrm{G} / \mathrm{T})$ were associated as protective haplotypes, while $\mathrm{H} 2(2 \mathrm{G} / \mathrm{A} / \mathrm{G} / \mathrm{A})$ and $\mathrm{H} 3(2 \mathrm{G} / \mathrm{A} / \mathrm{G} / \mathrm{T})$ were risk haplotypes. The haplotype carrying the $\mathrm{G}$ allele of -1690 is a protective haplotype, while the A allele of -1690 is a risk haplotype. Ladenvall et al. found that TAFI genotypes and haplotypes showed significant associations with TAFI levels. While no haplotype was found to have a significant association with overall ischemic stroke, subtype analysis revealed an association between the H2B haplotype and cryptogenic stroke and an association between the H1B haplotype and small-vessel disease [20]. As these results illustrate, haplotype analysis is helpful for deciphering the relationship between multiple SNPs and disease susceptibility. Our findings suggest that the haplotype of TAFI could be genetic a marker for ACI.

There are several limitations to this study. The small number of participants in this study was insufficient and therefore may have led to non-representative results. This limitation may have suppressed a true relationship due to a type II statistical error. A sample size with sufficient statistical power is critical to analyze the genetic associations of causal genes with complex diseases susceptibility. The sample size for detecting associations between disease and SNP markers is known to be highly affected by disease prevalence, disease allele frequency, linkage disequilibrium, inheritance models (e.g., additive, 
dominant, and multiplicative models), and effect size of the genetic variants (e.g., odds ratio, relative risk, etc.). Particular attention must be paid to sample sizes when more than one variable is studied simultaneously, such as multiple imperfectly correlated traits, intergenic interactions or gene-environment interactions [39]. Additionally, the comparatively small sample size, together with other environmental risks may mask the genuine differences in allele frequencies between cases and controls. Hong et al. suggested that a lower sample size for testing more common SNPs with stronger effect sizes and increased LD between marker allele and disease allele might contribute to achieve adequate statistical power [40]. Therefore, our results should be interpreted with caution. In addition, selection bias in the patient or control populations cannot be entirely excluded. The other clinical characteristics of the study group, such as hypertension, diabetes or hypercholesterolemia, might have complicated the associations between TAFI polymorphisms and ACI. Other functional polymorphisms might also influence TAFI expression, and their combined effects must be studied to improve the prediction of the occurrence, severity, and outcomes of ACI. Furthermore, the levels of TAFI were not evaluated. However, the primary purpose of our study was to establish a genetic reference for future studies. Thus, this investigation focused on assessing the association of different genetic polymorphisms of TAFI with the risk of developing ACI. Larger patient and control cohorts will be needed to confirm the association of TAFI gene polymorphisms with $\mathrm{ACI}$ in other populations.

\section{Conclusion}

Our study is the first to describe the existence of an association between the $-23452 \mathrm{G} / 1 \mathrm{G}$ and $-1690 \mathrm{~A} / \mathrm{G}$ polymorphisms of TAFI and the risk of developing ACI in a Chinese population. Our findings support the idea that polymorphisms of TAFI contribute to the development of ACI. Our study may provide clues for the evaluation of individual susceptibility to ACI as well as for effective measures for the control and prevention of ACI. More work is required to shed light on the role of TAFI in the pathogenesis of ACI and to further clarify its prognostic and therapeutic potential.

\section{Abbreviations \\ TAFI: Thrombin activatable fibrinolysis inhibitor; ACl: Atherosclerotic cerebral infarction; SNP: Single nucleotide polymorphism; RFLP: Restriction fragment length polymorphism; AS-PCR: Allele-specific polymerase chain reaction; TOAST: Trial of Org 10172 in Acute Stroke Treatment; OR: Odds ratio; Cl: Confidence interval; QTNs: quantitative trait nucleotides.}

\section{Competing interest}

The authors have no actual or potential conflicts of interest related to this manuscript. Appropriate approval was obtained, and the appropriate procedures were followed concerning human subjects.

\section{Authors' contributions}

LY, ZZL and ZJH carried out the molecular studies and drafted the manuscript. MGD, CLL and TH carried out the genotyping. CYY and LZJ performed the statistical analysis. CYS and LKS conceived of the study, and participated in its design and coordination. ZB helped to draft the manuscript. All authors read and approved the final manuscript.

\section{Acknowledgements}

This work was supported by funding from the National Nature Science Foundation of China (grant numbers 31171219, 81271213, 81070878,

81271214 and 81300929); the Natural Science Foundation of Guangdong Province, China (No. S2012010008222); and the Science and Technology Innovation Fund of Guangdong Medical College (No. STIF 201101).

Received: 27 March 2014 Accepted: 10 May 2014

Published: 13 May 2014

\section{References}

1. Juhan-Vague I, Renucci JF, Grimaux M, Morange PE, Gouvernet J, Gourmelin Y, Alessi MC: Thrombin-activatable fibrinolysis inhibitor antigen levels and cardiovascular risk factors. Arterioscler Thromb Vasc Biol 2000, 20:2156-2161.

2. Boffa MB, Hamill JD, Maret D, Brown D, Scott ML, Nesheim ME, Koschinsky ML: Acute phase mediators modulate thrombin-activable fibrinolysis inhibitor (TAFI) gene expression in HepG2 cells. J Biol Chem 2003, 278:9250-9257.

3. Virmani R, Ladich ER, Burke AP, Kolodgie FD: Histopathology of carotid atherosclerotic disease. Neurosurgery 2006, 59:S219-S227. discussion S213-213.

4. Colucci M, Semeraro N: Thrombin activatable fibrinolysis inhibitor: at the nexus of fibrinolysis and inflammation. Thromb Res 2012, 129:314-319.

5. Dichgans M: Genetics of ischaemic stroke. Lancet Neurol 2007, 6:149-161.

6. Hamsten A, Wiman B, de Faire U, Blombäck M: Increased plasma levels of a rapid inhibitor of tissue plasminogen activator in young survivors of myocardial infarction. N Engl J Med 1985, 313:1557-1563.

7. Silveira A, Schatteman K, Goossens F, Moor E, Scharpé S, Stromqvist M, Hendriks D, Hamsten A: Plasma procarboxypeptidase $\mathrm{U}$ in men with symptomatic coronary artery disease. Thromb Haemost 2000, 84:364-368

8. Santamaria A, Martinez-Rubio A, Borrell M, Mateo J, Ortin R, Fontcuberta J: Risk of acute coronary artery disease associated with functional thrombin activatable fibrinolysis inhibitor plasma level. Haematologica 2004, 89:880-881.

9. Schroeder V, MarianneWilmer BB, Kohler HP: TAFI activity in coronary artery disease: A contribution to the current discussion onTAFI assays. Thromb Haemost 2006, 96:236-237.

10. Zorio E, Castelló R, Falcó C, Espana F, Osa A, Almenar L, Aznar J, Estellés A: Thrombin-activatable fibrinolysis inhibitor in young patients with myocardial infarction and its relationship with the fibrinolytic function and the protein C system. Br J Haematol 2003, 122:958-965.

11. van Tilburg NHRFR, Bertina RM: Thrombin activatable fibrinolysis inhibitor and the risk for deep vein thrombosis[J]. Blood 2000, 95:2855-2859.

12. Eichinger $S$, Schönauer $V$, Weltermann A, Minar E, Bialonczyk C, Hirschl M, Schneider B, Quehenberger P, Kyrle PA: Thrombin-activatable fibrinolysis inhibitor and the risk for recurrent venous thromboembolism. Blood 2004, 103:3773-3776.

13. Verdú J, Marco P, Benlloch S, Sanchez J, Lucas J: Thrombin activatable fibrinolysis inhibitor (TAFI) polymorphisms and plasma TAFI levels measured with an ELISA insensitive to isoforms in patients with venous thromboembolic disease (VTD). Thromb Haemost 2006, 95:585-586.

14. Franco RF, Fagundes MG, Meijers JC, Reitsma PH, Lourenco D, Morelli V, Maffei FH, Ferrari IC, Piccinato CE, Silva WA Jr, Zago MA: Identification of polymorphisms in the 5 '-untranslated region of the TAFI gene: relationship with plasma TAFI levels and risk of venous thrombosis. Haematologica 2001, 86:510-517.

15. Henry M, Aubert H, Morange PE, Nanni I, Alessi MC, Tiret L, Juhan-Vague I: Identification of polymorphisms in the promoter and the 3 region of the TAFI gene: evidence that plasma TAFI antigen levels are strongly genetically controlled. Blood 2001, 97:2053-2058.

16. Boffa MB, Maret D, Hamill JD, Bastajian N, Crainich P, Jenny NS, Tang Z, Macy EM, Tracy RP, Franco RF, Nesheim ME, Koschinsky ML: Effect of single nucleotide polymorphisms on expression of the gene encoding 
thrombin-activatable fibrinolysis inhibitor: a functional analysis. Blood 2008, 111:183-189.

17. Biswas A, Tiwari AK, Ranjan R, Meena A, Akhter MS, Yadav BK, Behari M Saxena R: Thrombin activatable fibrinolysis inhibitor gene polymorphisms are associated with antigenic levels in the Asian-Indian population but may not be a risk for stroke. Br J Haematol 2008, 143:581-588.

18. Akatsu H, Yamagata H, Chen Y, Miki T, Kamino K, Takeda M, Campbell W, Kondo I, Kosaka K, Yamamoto T, Okada H: TAFI polymorphisms at amino acids 147 and 325 are not risk factors for cerebral infarction. $\mathrm{Br} J$ Haematol 2004, 127:440-447.

19. Kozian DH, Lorenz M, Marz W, Cousin E, Mace S, Deleuze JF: Association between the Thr325lle polymorphism of the thrombin-activatable fibrinolysis inhibitor and stroke in the Ludwigshafen Risk and Cardiovascular Health Study. Thromb Haemost 2010, 103:976-983.

20. Ladenvall C, Gils A, Jood K, Blomstrand C, Declerck PJ, Jern C: Thrombin activatable fibrinolysis inhibitor activation peptide shows association with all major subtypes of ischemic stroke and with TAFI gene variation. Arterioscler Thromb Vasc Biol 2007, 27:955-962.

21. Adams HP Jr, Bendixen BH, Kappelle $\sqcup$, Biller J, Love BB, Gordon DL, Marsh EE 3rd: Classification of subtype of acute ischemic stroke. Definitions for use in a multicenter clinical trial. TOAST. Trial of Org 10172 in Acute Stroke Treatment. Stroke 1993, 24:35-41.

22. Li K, Dai D, Zhao B, Yao L, Yao S, Wang B, Yang Z: Association between the RAGE G82S polymorphism and Alzheimer's disease. J Neural Transm 2010, 117:97-104.

23. Shi YY, He L: SHEsis, a powerful software platform for analyses of linkage disequilibrium, haplotype construction, and genetic association at polymorphism loci. Cell Res 2005, 15:97-98.

24. Takada K, Seike T, Sasaki T, Masuda Y, Ito A, Ishii H: Nobiletin, a polymethoxyflavone in citrus fruits, reduces TAFI expression in HepG2 cells through transcriptional inhibition. Thromb Haemost 2013, 109:1060-1069.

25. Leebeek FW, Goor MP, Guimaraes AH, Brouwers GJ, Maat MP, Dippel DW, Rijken DC: High functional levels of thrombin-activatable fibrinolysis inhibitor are associated with an increased risk of first ischemic stroke. J Thromb Haemost 2005, 3:2211-2218.

26. Kraft P, Schwarz T, Meijers JC, Stoll G, Kleinschnitz C: Thrombin-activatable fibrinolysis inhibitor (TAFI) deficient mice are susceptible to intracerebral thrombosis and ischemic stroke. PLoS One 2010, 5:e11658.

27. Juhan-Vague I, Morange PE, Aubert H, Henry M, Aillaud MF, Alessi MC, Samnegard A, Hawe E, Yudkin J, Margaglione M, Di Minno G, Hamsten A, Humphries SE, HIFMECH Study Group: Plasma thrombin-activatable fibrinolysis inhibitor antigen concentration and genotype in relation to myocardial infarction in the north and south of Europe. Arterioscler Thromb Vasc Biol 2002, 22:867-873.

28. Morange PE, Juhan-Vague I, Scarabin PY, Alessi MC, LuC G, Arveiler D, Ferrieres J, Amouyel P, Evans A, Ducimetiere P, group PS: Association between TAFI antigen and Ala147Thr polymorphism of the TAFI gene and the angina pectoris incidence. The PRIME Study (Prospective Epidemiological Study of MI). Thromb Haemost 2003, 89:554-560.

29. Tassies D, Roque M, Monteagudo J, Martorell T, Sionis A, Arzamendi D, Heras M, Reverter JC: Thrombin-activatable fibrinolysis inhibitor genetic polymorphisms as markers of the type of acute coronary syndrome. Thromb Res 2009, 124:614-618.

30. Sucker C, Hetzel GR, Farokhzad F, Dahhan F, Schmitz M, Kurschat C, Grabensee B, Maruhn-Debowski B, Zotz R, Scharf R: Association of genotypes of thrombin-activatable fibrinolysis inhibitors with thrombotic microangiopathies-a pilot study. Nephrol Dial Transplant 2007, 22:1347-1350.

31. Meltzer ME, Doggen CJ, de Groot PG, Meijers JC, Rosendaal FR, Lisman T: Low thrombin activatable fibrinolysis inhibitor activity levels are associated with an increased risk of a first myocardial infarction in men. Haematologica 2009, 94:811-818.

32. Guimaraes $\mathrm{AH}$, van Tilburg NH, Vos HL, Bertina RM, Rijken DC: Association between thrombin activatable fibrinolysis inhibitor genotype and levels in plasma: comparison of different assays. Br J Haematol 2004 124:659-665.

33. Frere C, Tregouet DA, Morange PE, Saut N, Kouassi D, Juhan-Vague I, Tiret $L$, Alessi MC: Fine mapping of quantitative trait nucleotides underlying thrombin-activatable fibrinolysis inhibitor antigen levels by a transethnic study. Blood 2006, 108:1562-1568.
34. Boffa MB, Hamill JD, Bastajian N, Dillon R, Nesheim ME, Koschinsky ML: A role for CCAAT/enhancer-binding protein in hepatic expression of thrombinactivable fibrinolysis inhibitor. J Biol Chem 2002, 277:25329-25336.

35. Maret D, Boffa MB, Brien DF, Nesheim ME, Koschinsky ML: Role of mRNA transcript stability in modulation of expression of the gene encoding thrombin activable fibrinolysis inhibitor. J Thromb Haemost 2004, 2:1969-1979.

36. Adali E, Yildizhan R, Kurdoglu M, Bugdayci G, Kolusari A, Sahin HG: Increased plasma thrombin-activatable fibrinolysis inhibitor levels in young obese women with polycystic ovary syndrome. Fertil Steril 2010, 94:666-672

37. Erdogan M, Karadeniz M, Alper GE, Tamsel S, Uluer H, Caglayan O, Saygili F, Yilmaz C: Thrombin-activatable fibrinolysis inhibitor and cardiovascular risk factors in polycystic ovary syndrome. Exp Clin Endocrinol Diabetes 2008, 116:143-147.

38. Morris RW, Kaplan NL: On the advantage of haplotype analysis in the presence of multiple disease susceptibility alleles. Genet Epidemiol 2002, 23:221-233.

39. Cardon LR, Bell Jl: Association study designs for complex diseases. Nat Rev Genet 2001, 2:91-99.

40. Hong EP, Park JW: Sample size and statistical power calculation in genetic association studies. Genomics Inform 2012, 10:117-122.

doi:10.1186/1476-511X-13-80

Cite this article as: Li et al:: Association between polymorphisms in the flanking region of the TAFI gene and atherosclerotic cerebral infarction in a Chinese population. Lipids in Health and Disease 2014 13:80

\section{Submit your next manuscript to BioMed Central and take full advantage of:}

- Convenient online submission

- Thorough peer review

- No space constraints or color figure charges

- Immediate publication on acceptance

- Inclusion in PubMed, CAS, Scopus and Google Scholar

- Research which is freely available for redistribution 